\title{
A quantitative Golgi study of basal dendrites of hippocampal CA1 pyramidal cells in senile dementia of Alzheimer type
}

\author{
MASAHITO YAMADA, * YOSHIAKI WADA, $\dagger$ HIROSHI TSUKAGOSHI, * \\ EI-ICHI OTOMO, $\dagger$ MICHIO HAYAKAWA $\ddagger$ \\ From the Department of Neurology, Tokyo Medical and Dental University* and Departments of Internal \\ Medicine $\dagger$ and Pathology, $\ddagger$ Yokufukai Geriatric Hospital, Tokyo, Japan
}

SUMMARY Basal dendrites of hippocampal CA1 pyramidal cells in senile dementia of Alzheimer type (SDAT) were studied quantitatively by the Golgi impregnation method. The present data suggested that basal dendrites of the pyramidal cells were decreased in number in SDAT, and that the dendritic decrease was associated with a decrease in size of their cell bodies.

Senile dementia of Alzheimer type (SDAT) is pathologically characterised by changes in the cerebral cortex including abundant neuritic plaques and neurofibrillary tangles (NFTs), and the death of the neurons. The hippocampal formations, which are known to be related to learning and memory functions, show prominent changes in the cellular architecture in SDAT. ${ }^{1}$

We report a quantitative Golgi study on the basal dendrites of hippocampal CA1 pyramidal cells in SDAT and the relationship between the dendritic changes and size of the cell bodies.

\section{Materials and methods}

Three cases of SDAT (aged 80, 90, and $90 \mathrm{yr}$ ) with progressive dementia over several years and with typical neuropathological findings were studied with three agematched control cases (aged 83, 85, and $90 \mathrm{yr}$ ). The necropsies were performed within 10 hours post mortem. Formalin-fixed hippocampal regions were cut into blocks 4-5 mm thick. The blocks were immersed in $3 \%$ potassium dichromate for a week at $25^{\circ} \mathrm{C}$. Then they were washed with water for a few minutes and placed in $1.5 \%$ silver nitrate for a week at $25^{\circ} \mathrm{C}$. The blocks were then dehydrated in alcohol and embedded in $14 \%$ celloidin, and cut serially into sections

Address for reprint requests: Dr $M$ Yamada, Department of Neurology, Tokyo Medical and Dental University, 1-5-45, Yushima, Bunkyo-ku, Tokyo 113, Japan.

Received 9 February 1988.

Accepted 2 April 1988 of $100 \mu \mathrm{m}$ thickness. The sections were dehydrated in alcohol, cleared in toluene, and mounted.

For each brain, 20 representative pyramidal cells in the CA1 region ${ }^{2}$ were selected randomly from completely impregnated cells which had soma located near the centre of the thickness of the section and were not obscured by other tissue elements and precipitated debris. Basal dendrites in each of the selected cells were analysed quantitatively using Sholl's concentric circle method. ${ }^{3}$ Concentric circles centring on the cell body were drawn with radii of $40 \mu \mathrm{m}$ to $200 \mu \mathrm{m}$ at $20-\mu \mathrm{m}$ intervals, and the number of basal dendrites intersecting each circle of a series of concentric circles was counted. The total number of the dendritic intersections within a $200-\mu \mathrm{m}$ radius in each cell was also calculated. The total number of the dendritic intersections (DIs) and number of DIs of each concentric circle were compared in the patients and controls.

Subsequently, in an attempt to elucidate the relationship between changes of the dendrites and cell bodies, sizes of the cell bodies of the completely impregnated cells were measured. Area of the soma in each CAl pyramidal cell was measured three times by an image analyser, Kontron MOP. 20 , and mean value of the data was used for the size of the cell body. The areas of the cell bodies were compared in the following three groups of the hippocampal CAl pyramidal cells; 20 cells randomly chosen from the controls; 10 cells with a marked loss of the basal dendrites from the patients; and 10 cells with well-preserved basal dendrites from the patients.

\section{Results}

The CAl pyramidal cells with shrinkage of basal dendritic trees were frequently found in the patients with 


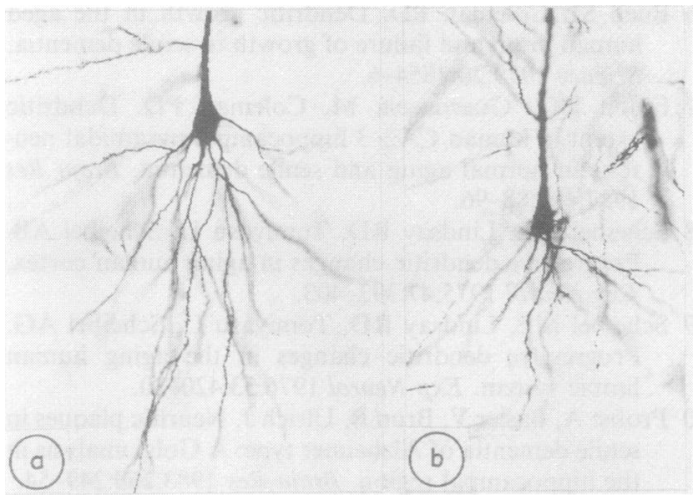

Fig Hippocampal CAl pyramidal cells in a control case (a) and in a patient with senile dementia of Alzheimer type ( $S D A T)$ (b). SDAT shows shrinkage of the basal dendritic trees compared with control. (a, b; Golgi stain, $\times 210)$.

SDAT compared with controls (fig). Differences in the dendritic arborisation between the patients and controls were quantitative as described below, and no qualitative difference was present between them.

The total number of intersections for basal dendrites of pyramidal cells (mean, SD) was $113 \cdot 2,16 \cdot 3$ in the controls and $73 \cdot 3,21 \cdot 1$ in the patients with SDAT. The patients showed a significantly lower number of total intersections than the controls $(p<0.001$ by Student's $t$ test).

The number of intersections for basal dendrites (DIs) of pyramidal cells as a function of distance from the cell body are shown in the table. The dendritic density was maximum at the $60 \mu \mathrm{m}$ sphere in both the patients and controls. The number of DIs was significantly lower in the patients at any sphere than in the controls.

The mean size of the cell bodies of the pyramidal cells in controls (total DIs: $111 \cdot 1,15 \cdot 2$ ) was 734 , $170 \mu \mathrm{m}^{2}$. The mean size of the cell bodies of the pyramidal cells with a significant decrease of basal dendrites (total DIs; $45 \cdot 0,8 \cdot 8$ ) in the patients was 544 ,
$169 \mu \mathrm{m}^{2}$ and was significantly smaller than that in controls ( $p<0.01$ by Student's $t$ test). The mean size of the cell bodies of the pyramidal cells with wellpreserved basal dendrites (total DIs; 106.7, 8.8) in the patients was $696,210 \mu \mathrm{m}^{2}$ and was not significantly different from that in controls.

\section{Discussion}

The present study demonstrated that basal dendrites of the hippocampal CAl pyramidal cells were decreased in number in SDAT, although there was no abnormal pattern of dendritic growth as reported in Alzheimer's presenile dementia ${ }^{4}$ and that a decrease in number of the basal dendrites was associated with a decrease in the size of the cell bodies. There have been some quantitative s-7 $^{5}$ and qualitative ${ }^{8-10}$ studies on the dendritic changes in SDAT. Concerning hippocampal formations, loss of spines along apical dendrites of the pyramidal cells ${ }^{5}$ and maintenance of dendritic trees of CA2-3 pyramidal cells ${ }^{7}$ were quantitatively reported in SDAT. Disappearance of dendrites of hippocampal pyramidal cells was described qualitatively in the aged people including demented patients. ${ }^{9}$ There have been no reports of quantitative study on basal dendrites of hippocampal CAl pyramidal cells.

The hippocampal CAl zones, which receive the output mainly from the CA3 zones and have projections to subiculum, entorhinal cortex, and other areas, ${ }^{11}$ are very affected in SDAT. ${ }^{1}$ In SDAT, hippocampal CA1 pyramidal cells showing shrinkage of the cell bodies with or without NFTs, are frequently recognised in usual histological preparations. Our study indicates that those cells accompany shrinkage of the basal dendritic trees. The neuronal atrophy affecting both the cell bodies and dendritic trees found in the present study appear to show a process of neuronal death, and would be closely related to progressive mental deterioration in SDAT.

Table Number of intersections for basal dendrites of hippocampal CAI pyramidal cells as a function of distance from the cell body in the controls and patients with senile dementia of Alzheimer type

\begin{tabular}{|c|c|c|c|c|c|}
\hline \multirow{2}{*}{$\begin{array}{l}\text { Distance from } \\
\text { the soma } \\
(\mu \mathrm{m})\end{array}$} & \multicolumn{2}{|c|}{ Controls } & \multicolumn{2}{|c|}{ Patients } & \multirow{2}{*}{$\begin{array}{l}\text { Significance } \\
(p)\end{array}$} \\
\hline & Mean & $S D$ & Mean & $S D$ & \\
\hline 40 & 15.0 & $1 \cdot 8$ & 11.9 & $2 \cdot 9$ & $<0.01$ \\
\hline 60 & $18 \cdot 2$ & $2 \cdot 0$ & 13.9 & 2.9 & $<0.01$ \\
\hline 80 & $18 \cdot 1$ & 2.9 & $12 \cdot 9$ & 3.0 & $<0.01$ \\
\hline 100 & 16.5 & 2.9 & 10.9 & 3.4 & $<0.01$ \\
\hline 120 & $14 \cdot 2$ & 3.0 & 9.0 & 3.9 & $<0.01$ \\
\hline 160 & $9 \cdot 2$ & $3 \cdot 2$ & $4 \cdot 4$ & $3 \cdot 3$ & $<0.01$ \\
\hline 180 & $6 \cdot 3$ & $2 \cdot 8$ & $2 \cdot 4$ & $2 \cdot 2$ & $<0.01$ \\
\hline 200 & $3 \cdot 7$ & $2 \cdot 7$ & $1 \cdot 1$ & $1 \cdot 3$ & $<0.01$ \\
\hline
\end{tabular}

*Student's $t$ test. 


\section{References}

1 Hyman BT, Van Hoesen GW, Damasio AR, Barnes CL. Alzheimer's disease: Cell-specific pathology isolates the hippocampal formation. Science 1984;225: 1168-70.

2 Lorente de No, R. Studies on the structure of the cerebral cortex. II. Continuation of the study of the ammonic system. J Psychol Neurol 1934;46:113-77.

3 Sholl DA. Dendritic organization in the neurons of the visual and motor cortices of the cat. J Anat 1953; 87:387-406.

4 Scheibel AB, Tomiyasu U. Dendritic sprouting in Alzheimer's presenile dementia. Exp Neurol 1978; 60:1-8.

5 Mehraein P, Yamada M, Tarnowska-Dziduszko. Quantitative study on dendrites and dendritic spines in Alzheimer's disease and senile dementia. In: Kreutzberg GW, eds. Advances in Neurology, Vol. 12.
New York: Raven Press, 1975:453-8.

6 Buell SJ, Coleman PD. Dendritic growth in the aged human brain and failure of growth in senile dementia. Science 1979;206:854-6.

7 Flood DG, Guarnaccia M, Coleman PD. Dendritic extent in human CA2-3 hippocampal pyramidal neurons in normal aging and senile dementia. Brain Res 1987;409:88-96.

8 Scheibel ME, Lindsay RD, Tomiyasu U, Scheibel AB. Progressive dendritic changes in aging human cortex. Exp Neurol 1975;47:392-403.

9 Scheibel ME, Lindsay RD, Tomiyasu U, Scheibel AG. Progressive dendritic changes in the aging human limbic system. Exp Neurol 1976;53:420-30.

10 Probst A, Basler V, Bron B, Ulrich J. Neuritic plaques in senile dementia of Alzheimer type: A Golgi analysis in the hippocampal region. Brain Res 1983;268:249-54.

11 Schwerdtfeger WK. Structure and Fiber Connection of the Hippocampus. A Comparative Study. Berlin: Springer-Verlag, 1984. 